Wśród rozlicznych zagadnień szczegółowych i przesłań dla teraźniejszości - podejmowanych i formułowanych $w$ trakcie dwudniowych obrad $w$ sekcji - na uwage zasługują m.in. kwestie łączące się z problemem uniwersalizmu pedagogicznego i postulatem koordynacji wysiłków zarówno wychowawczych, jak i badawczych (w dziedzinie edukacji) w perspektywie ponadnarodowej. Podczas dyskusji podkreślano znaczenie tradycji wychowawczej w kontekście potrzeb oraz zadań współczesnej teorii i praktyki edukacyjnej, eksponowano idę̨ - lansowaną już w Polsce międzywojennej przez Bogdana Nawroczyńskiego i Sergiusza Hessena, a po wojnie m.in. przez Bogdana Suchodolskiego - „dialogu współczesnego pedagoga z pedagogami minionych wieków i pokoleń". Wyrażano wręcz pogląd, że przy opracowywaniu współczesnych rozwiązań wychowawczych należy odwoływać się do dziedzictwa pedagogicznego, uwzględniając te jego elementy, które pozostają w dużej mierze jeszcze żywe i pozwalają lepiej zrozumieć teraźniejszość i nadchodząca przyszłość. Zwracano uwage, że spośród wielu funkcji tradycji szczególne znaczenie mają te, które łączą się z zaspokojeniem tak potrzeby zakorzenienia, jak i przewidywania. Nawiązywanie do tradycji - co podkreślano - ma odpowiedzieć nie tylko na pytanie, w jakim kierunku edukacja zdążała, lecz również ku czemu zmierza ona dzisiaj i ku czemu zmierzać powinna.

Wieslaw Jamrożek

\title{
Międzynarodowa konferencja historyków wychowania w WSP Rzeszów
}

W dniach 12 - 14 października 1998 roku zorganizowana została staraniem Zakładu Historii Wychowania Międzynarodowa Konferencja Naukowa na temat „Pedagogika nowego wychowania w Polsce u schyłku XIX i w pierwszej połowie XX wieku (podstawowe przejawy i współczesne odniesienia)".

Obradujące w Rzeszowie i Czudcu reprezentatywne forum historyków oświaty i wychowania, zainteresowanych nowszymi dziejami teorii i praktyki edukacyjnej zgromadziło 60-ciu uczestników z wszystkich niemal ośrodków akademickich w Polsce. W konferencji wzięli udział także goście z sąsiedniej Ukrainy i Słowacji.

Idea konferencji, jej problematyka naukowa nawiązywały do genezy i kierunków rozwoju znamiennego fenomenu myśli pedagogicznej i praktyki szkolnej przełomu wieków, który zaowocował w światowej, europejskiej i polskiej oświacie różnorodnymi koncepcjami, śmiałymi pomysłami i eksperymentami pedagogicznymi.

Glówną przesłanką dla podjęcia tej problematyki stały się zauważalne w ostatnich latach silne dążenia do gruntownej przebudowy szkoły w duchu aktywności osobowej, otwartości intelektualno-poznawczej i autonomii duchowo-emocjonalnej, respektującej indywidualną samorealizację jednostki i osoby ludzkiej. Są to więc idee, hasła nowej filozofii edukacyjnej inspirowanej amerykańską szkołą progresywną, europejskim modelem szkoły aktywnej (pracy) i polską koncepcją szkoły twórczej, całej rozległej formacji „nowego wychowania".

Innym powodem zachęcającym do rekonstrukcji i współczesnej reinterpretacji zwróconej ku tamtej myśli pedagogicznej jest jej uniwersalność, wielokierunkowość i wieloznaczność, ale również paradoksalne zaniechanie przez wiele dziesięcioleci "nowej pedagogiki", jak też ponowne jej "odkrycie" we współczesnym nurcie pedagogiki krytycznej. 
Retrospektywne spojrzenie na myśl „nowego wychowania” dotyczyło również charakteru i zakresu polskiej recepcji nowych idei oświatowych przełamujących dziedzictwo szkoły tradycyjnej, idei, które zaowocowały także w Galicji wybitnymi dziełami w literaturze pedagogicznej, ważnymi również dla współczesnej teorii i praktyki szkoły.

Trzydniowa konferencja, której obrady otworzył Rektor WSP w Rzeszowie - prof. dr hab. W. Bonusiak zainaugurowana została sesją plenarną pod kierownictwem prof. dr hab. C. Majorka.

Referaty wprowadzające wygłosili prof. dr hab. D. Dryndowa (UŚ), nt. „Geneza nowego wychowania w Polsce" oraz prof. dr hab. A. Meissner (WSP Rzeszów) poświęcając swoje wystąpienie naukowej sylwetce H. Rowida i jego „drodze do szkoły twórczej”.

Temu też wybitnemu pedagogowi, współtwórcy koncepcji ,.,szkoły twórczej”, absolwentowi Seminarium Nauczycielskiego w Rzeszowie, wykładowcy psychologii i pedagogiki w UJ poświęcona została pamiątkowa tablica odsłonięta przez nestorkę polskiej historii wychowania, prof. dr hab. Eugenię Podgórską i Rektora prof. dr W. Bonusika.

Bogata problematyka naukowa konferencji pomieszczona została $w$ czterech sekcjach tematycznych, ukierunkowanych na rozważania w zakresie następujących zagadnień. Obrady sekcji I poświęcone były „genezie i glównym nurtom nowego wychowania”. Jej przebiegiem kierował prof. dr hab. J. Szmyd (WSP Kraków). W pracach zespołu wzięło udział 13 uczestników. Rozważania sekcji II dotyczyły „prób upowszechniania idei nowego wychowania w Polsce i za granica". Rolę moderatora petniła prof. dr hab. E. Sapia-Drewniak (U w Opolu). W kręgu tej tematyki przedstawiono 16 referatów.

W sekcji III swoje referaty w dziedzinie „nowatorstwa pedagogicznego w Polsce i w Europie doby międzywojennej" przedstawiło 16 autorów. Obradami kierował prof. dr hab. Cz. Majorek. Sekcja IV zajełła się prezentacją sylwetek „ludzi nowego wychowania w Polsce i za granic̨̨”. W tej grupie tematycznej zabrało glos 13 osób. Moderatorem tego zespołu problemowego była prof. dr hab. D. Koźmian (U. Szczeciński).

Konferencje zamykała sesja plenarna, na której przedstawiono sprawozdania $z$ obrad i dyskusji w zespołach problemowych. Podkreślono, że poziom naukowy pracy poszczególnych zespołów był wysoki i przyniósł liczący się dorobek poznawczy i interpretacyjny w zakresie podejmowanych zagadnien.

W referacie końcowym prof. dr hab. B. Śliwerski dokonał analizy zagadnień dotyczących „autonomii i uspołecznienia szkół u progu XXI wieku”. Obok pogłębionych i śmiałych refleksji dotyczących współczesnych i przyszłych wizji modelowo-pedagogicznych i programowo-organizacyjnych, autor wiele uwagi poświęcił krytycznej ocenie szeregu aspektów projektowanej reformy oświaty.

Podsumowania i naukowej rekapitulacji konferencji dokonał prof. dr hab. Cz. Majorek, który w analitycznym wystąpieniu zwrócił uwagę na aktualność i doniosłość zrealizowanej przez konferencję problematyki historyczno-edukacyjnej. Podkreślił wartość poznawczą i naukową konferencji, jej uniwersalny charakter wiążący tradycje ze współczesnymi problemami edukacji i reform oświatowych. W tym kontekście wskazał na źródła, uwarunkowania, ciągłość i tożsamość teorii i praktyki edukacyjnej, zwrócił uwage na pożądane kierunki badań w zakresie problematyki, która była treścią konferencji.

Na zakończenie obrad głos zabrał prof. dr hab. A. Meissner, który w imieniu organizatorów podziękował uczestnikom konferencji za twórczy wkład w dzieło współczesnej rekonstrukcji idei edukacyjnych „nowego wychowania”. Zapowiedział opublikowanie przedstawionych materiałów naukowych w ramach cyklu wydawniczego WSP w Rzeszowie - „Galicja i jej dziedzictwo". 